\title{
The Role of Edmodo Model for Professional Development: The Uses of Blockchain in School Management
}

\author{
https://doi.org/10.3991/ijet.v15i12.13571 \\ Fahriye Altınay $(\varpi)$ \\ Near East University, Northern Cyprus, \\ fahriye.altinay@neu.edu.tr \\ Özge Beyatlı \\ Ministry of Labor and Labor Security, Nicosia, Northern Cyprus \\ Gokmen Dagli \\ University of Kyrenia, Kyrenia, Northern Cyprus \\ Zehra Altınay \\ Near East University, Nicosia, Northern Cyprus
}

\begin{abstract}
Schools are social agents to diffuse merits of technology. The uses of technology foster professional development. Schools have started to make tendencies towards digitalization. Especially learning and teaching contexts become technology supported. In this respect, school infrastructure and learning resources have changed. Teachers play a great role to adopt new changes in learning teaching process to the new generation. This makes innovation in schools to use new technologies and applications for better education practices. This research study aims to create awareness on Edmodo model to teachers and develop their skills on new learning contents for establishing more digitalized school at the secondary education level and analyze the uses of blockchain in school management. The research study was conducted with 21 volunteer teachers working at the secondary level that they get training on the use of Edmodo Content Management System. Case study through action research was done in this research study that self-report was used to gain experiences of teachers. By this way, educational online environment was created for teachers for the uses of learningteaching process. Research results revealed that teachers enhance their skills and knowledge about the use of the Edmodo content management system increased compared to the pre-seminar. In addition, they gained online collaboration and research skills. This practice created the culture of technology based innovation for their schools.
\end{abstract}

Keywords-Blockchain, Edmodo, Content management system, Social networks, Professional development 


\section{Introduction}

Internet has become an indispensable part of our lives due to the rapid progress of developments in information and communication technologies in the 21st century. Thanks to internet, individuals reach desired information any time and communication between individuals in different places of the world is becoming easier.

Main aim in the education system is success. Studies and new searches for improving success highlight the system of governance in education. Success is a chaotic topic and it is linked to more than one factor. For example, for these factors, countries historical savings, political and economic situations, the sum of sources that are reserved for education, qualifications of teachers, family styles, the importance that is given to education by political structure and physical opportunities of educational institutions can be counted.

Technology and internet leads to changes in several areas including education and training. [1]; [2] emphasized in their study that integrating information and communication technologies in learning and teaching processes was necessary in order to increase student performance. Information and communication technologies not only facilitate learning; they also help effective learning $[3,4,5]$. The study of [3] underlines the importance of digitalization and changes in school systems through the importance of technology. In addition, having a culture in school within the framework of adoption and diffusion of technology is crucial for making professional development and innovation.

Especially with Web 2.0 technologies, individuals communicate with each other, make friends, and share videos, photos, course contents etc. using social settings. Using Web 2.0 tools in education ensures that learners enjoy permanent learning [6], undertake the responsibility of self-learning, strengthen their relations with group works and improve advanced thinking abilities [7].

Social networks which are products of Web 2.0 technologies allow online chat and content sharing as well as introducing oneself by means of areas of interest, personal information and photographs; they also provide an environment where students can interact using their works and participate in cooperative formations. The fact that today's students can effectively use social networks has been noticed by teachers and studies were initiated on how to use social networks as a tool for learning and teaching $[8,9]$. Effective use of social networks in education settings provides such advantages as increasing the learning of students, including them in learning processes, improving their motivation, developing their writing skills, and facilitating teacher-student and studentstudent interaction [10].

Social network settings not only make learning and teaching in classroom environment easier; they also provide effective learning environment to people outside the classroom. Contrary to these advantages, it is stated that using social networks in education settings can affect learning process in negative direction [11, 12].

The study of [13] gives an insight of being global citizenship and underlines the importance of having technological and managerial skills in the transformation of education. In this respect, being leader and managing technology become crucial to foster knowledge construction [14]. 
Social networks become people to be connected and exchanging the ideas, information. It becomes medium of learning and make learners be active and inclusive to the learning context. Although social networks have positive sights, it is claimed that using social networks compromise the authority of the teacher in classroom [14] and that increase of usage frequency is correlated with the decrease of average grades of students $[15,16]$. According to [15] teachers and parents make more deliberate use of social networking sites due to such problems and that some schools have even banned the usage of social networks. Opposite to claimed discussions, educative social network sites play a great role to induct learners to the learning context and emerge the uses of technology in interaction and collaboration. "Edmodo" can be given as an example to such sites. Educative social networking sites allow for teachers and students to use social network technologies for educative purposes; they also ensure that security and confidentiality problems can be minimized [17].

The fact that Edmodo is similar in its appearance to Facebook, which is one of the most widely used social networking sites, increased its popularity among students [17]. Edmodo is a global education network which helps all students to connect people and resources which they need to fully realize their potentials. The advantages provided by Edmodo to teachers are as follows: non-registered people do not have access to the site, teachers can prevent uncontrolled participation in classes, and it provides a secure education environment which prevents abuse of information on students for malign purposes [17].

The uses of blockchain is a new platform for the school management. The applications in storing records, learning identity verification, information security, lifelong learning for the ownership and protection of content make the potential value of blockchain in education. School management has an intensified need to moderate merits of blockchain by increasing the capacity of participatory management through the uses of blockchain system.

In this respect, school management gains a value for the trust, security through the uses of block chain. The subjects of governance and data mining are new; therefore, education administrators have not got information at sufficient level to foster learning [18].

With the development of mobile, connected and personal technologies, mobile learning has become a basic TEL paradigm with the merits of blockchain system. Mobile learning emphasizes the use of mobile devices and, unlike traditional types of education, focuses on student mobility. It also emphasizes that learning can take place anytime and anywhere without the limitations of time, location and environment. Designs that combine both real and virtual learning environments are significant in intelligent education.

As the blockchain system become a merit for the qualification and verification of school management, partnership, collaboration and support for to open opportunities for the school environments to reconsider and use new learning structures become important. All data that will be obtained from every shareholder during the process of governance should be evaluated healthfully and a mechanism which will produce administrative results from the available sources should be created. Data mining comes first among the important tools for this process. Blockchain application in education 
especially in school management plays a great role to gain trust and security for the quality [19].

The uses of blockchain models in management especially in schools make decreasing the costs and increasing the validations.

It has been witnessed in the literature in recent years that educative online settings have made contribution to education environments. They particularly provide an effective learning environment in terms of increasing interaction between students, continuing communication after the class and integrating these settings in the course process for more permanent learning. In this sense, it has been essential to examine the role of Edmodo in learning-teaching processes as an education-oriented social learning network [20].

Today there is need for individuals who are able to think, produce, apply what they think and find solutions to problems. Integrating new technologies, applications and settings in learning and teaching processes in educating such individuals is essential so as to ensure effectiveness of learning. In this case, it is particularly necessary to ensure the adaptation of teachers, who will integrate these innovations in learning-teaching processes, to new technologies or applications. In this context keeping teachers posted about these innovations displays the essence of this research.

Currently, in addition to the practices implemented for teaching in learning-teaching process, the change in learning settings is remarkable. It is clear that educative online settings make contribution to learning and teaching processes, increase student motivation for the course and make positive contribution to education settings. In this context, the purpose of this study is to examine the use of Edmodo, which is an educative online setting for teachers aiming at evaluating Edmodo Content Management System Education which is designed for secondary school teachers and to gain opinions concerning the usage of Edmodo in learning-teaching process.

The sub-objectives determined in order to reach this goal are as follows:

- What is the level of secondary school teachers as regards Edmodo Content Management system?

- What are the opinions of secondary school teachers concerning the usage of Edmodo Content Management system in learning-teaching process?

- What are the opinions of secondary school teachers concerning awareness in the end of Edmodo Content Management system seminar?

\section{Materials and Methods}

In this section, detailed information is given on research model, study group, data collection process, data collection tools, research process and application, preparation of education setting, application and the role of the researcher. 


\subsection{Model of the research}

The objective of this study is to provide education on Edmodo to secondary school teachers at Ministry of National Education of Turkish Republic of Northern Cyprus and obtain the opinions of these teachers on Edmodo; thus the study was conducted using qualitative research method. [21] defined qualitative study as "a knowledge-producing process with a view to understand the lifestyles, stories, behaviors, organizational structures of people and social change".

In the research, "Case Study" model has been used among qualitative research methods. Case study is a method which examines one or more cases, situations, settings or interconnected systems in depth [22]. Understanding the case is an essential element of data analysis which deserves elaboration. Data are mostly obtained from interviews, field observations and documents" [23].

\section{$2.2 \quad$ Study group}

The pilot study group of the research consists of 138 of the 221 teachers who worked at Near East College in academic year.

The study group which received education in the study consisted of 21 volunteer teachers who worked at secondary level and participated in "Usage of Edmodo Content Management System" series of seminars.

\subsection{Data collection process}

In the data collection stage of the study, needs analysis was conducted with the purpose of determining the knowledge, skill and experience level of teachers as regards Edmodo content management system. Semi-structured interviews were conducted with teachers using interview forms and these interviews were recorded. Later, the interview records were transcripted. Prior to attending at "Usage of Edmodo Content Management System" seminar a preliminary evaluation form was used in order to determine the preliminary information level of teachers concerning Edmodo. Then a final evaluation for was applied with the purpose of determining the acquisitions of teachers at the end of the seminar.

\subsection{Data collection tools}

During data collection, needs analysis was conducted as the first step. In the needs analysis, 3 open-ended interview questions were prepared which were developed by the researcher with the purpose of determining the information level of teachers. At the stage of preparing open-ended interview questions, literature search was conducted and problems and expectations were taken into consideration. While preparing the openended questions, recognized principles were taken into consideration and attention was paid to ensure that they were understandable, free from direction and multi-dimensionality, made use of alternative questions and were organized in a logical order [24]. The prepared open-ended questions were evaluated by 2 field experts, 1 language expert, 
and 1 measuring and assessment expert. Based on the feedback provided by the experts, corrections were made and the final form was given to the questions. In addition, other data collection tools used in the study were preliminary evaluation form and final evaluation form.

\subsection{Preparation of education setting and designing of materials}

At the preparation of education setting stage, as it would be possible to follow the face-to-face classes online at uzem.neu.edu.tr address, an application was filed to Distance Education Centre Directorate of Near East University. This system was chosen because the participants were knowledgeable about the usage of Edmodo Content Management System, it provided a high-quality education setting, and it was a course management system which was previously experienced.

\subsection{Application}

Usage of Edmodo Content Management System seminar consisted of 21 participants who worked at secondary stage of Ministry of National Education schools. Participants who attended the seminar brought their laptop computers with them. Those who did not have their laptop computers participated in the class using their smart phones. Wireless internet was provided to the participants at the classroom where the seminar was organized.

Course contents were prepared using "Microsoft Power Point" program and reflected using a projection so that participants could follow. In addition, application was performed with participants and EDMODO program was covered step by step. At the end of each class, course contents were uploaded on Uzem system by means of an audiovisual video which was produced using "Camtasia 9 Studio" program.

\subsection{Analyzing and interpreting the data}

In the study, interview questions prepared in order to determine the needs of teachers working at secondary stage concerning the usage of Edmodo Content Management System, findings obtained from Needs Analysis, findings obtained from preliminary evaluation form and findings obtained from final evaluation form were analyzed based on their answers using content analysis method.

\subsection{Reliability and validity}

In order to ensure the validity and reliability of the study, internal validity (plausibility), external validity (transmissibility), internal reliability (consistency) and external validity (repeatability) actions were taken. 


\subsection{Researcher and role}

After having obtained the necessary permissions required for performing the needs analysis in order to determine the problem, the researcher passed on to application stage. In the light of identified needs, preparations were launched for the education seminar which was delivered by the researcher to teachers who worked at secondary stage. Seminar promotion posters were prepared and teachers were informed. Seminar topics were organized using Power Point presentation program; in addition, course contents which were uploaded to distance education center system were prepared using Camtasia Studio 9 program. Following the preparations, seminar process was initiated.

\section{$3 \quad$ Finding and Interpretations}

In qualitative research process the perceptions of participants concerning Edmodo Content Management System Application and obtained findings are included.

\subsection{Findings on needs analysis}

In the needs analysis, 138 of the 221 teachers answered the questions. Needs analysis questions consist of 3 open-ended questions. The themes related to the open-ended interview questions are given below. Need analysis becomes an evidence on understanding the nature of awareness on the use of new application in education context and learning process.

Table 1. Findings concerning answers given to the question "What is the contribution of Edmodo application to language education?" in the needs analysis form

\begin{tabular}{|l|l|c|}
\hline Teachers (138 persons) & Perceptions concerning language education of Edmodo application & F \\
\hline \multirow{4}{*}{} & Opportunity for effective communication & 26 \\
\cline { 2 - 3 } & It makes positive contribution & 18 \\
\cline { 2 - 3 } & It has no contribution & 17 \\
\cline { 2 - 3 } & Does not know/No answer & 77 \\
\hline
\end{tabular}

An examination of Table 1 shows that, among the 138 answers to the question "What is the contribution of Edmodo application to language education?", 26 people mentioned "effective communication opportunity", 18 people said "it had positive contribution", 17 people said "it has no contribution", and 77 people said "I have no information" and thus did not answer the question. These questions shed a light on the awareness on new application in language education. 
Table 2. Findings concerning the answers given to the question "what are your opinions and recommendations as regards Edmodo?" in the needs analysis

\begin{tabular}{|l|l|c|}
\hline Teachers (138 persons) & Perceptions concerning language education of Edmodo application & F \\
\hline \multirow{3}{*}{} & Opportunity for effective communication & 26 \\
\cline { 2 - 3 } & It makes positive contribution & 18 \\
\cline { 2 - 3 } & It has no contribution & 17 \\
\hline
\end{tabular}

An examination of Table 2 shows that among the 138 answers to the question "what are your opinions and recommendations as regards Edmodo?" 11 people said "it affects education positively", 6 people explained "it is not an effective system", 1 person said "lack of infrastructure. It is witnessed that 120 people did not answer the question as they did not have any information. It is clear that a majority of teachers do not have adequate information concerning Edmodo content management system.

Table 3. Findings concerning the answers given to the question "do you think that Edmodo application has deficiencies?" in the needs analysis

\begin{tabular}{|l|l|c|}
\hline Teachers (138 persons) & \multicolumn{1}{|c|}{ Deficiencies of Edmodo application } & F \\
\hline \multirow{4}{*}{} & Technological infrastructure deficiency & 2 \\
\cline { 2 - 3 } & It has deficiencies & 4 \\
\cline { 2 - 3 } & It does not have any deficiencies & 11 \\
\cline { 2 - 3 } & Does not know/No answer & 121 \\
\hline
\end{tabular}

An examination of Table 3 shows that among the 138 answers to the question "do you think that Edmodo application has deficiencies?", 2 people indicated technological infrastructure deficiencies, 4 people said "it has deficiencies", 11 people said "it has no deficiencies", and the remaining 121 people did not answer the question as they did not have any information on the application.

\subsection{Findings obtained from preliminary evaluation form}

Preliminary evaluation form consists of 4 open-ended questions. Below themes related to open-ended preliminary interview form are provided.

Table 4. Findings concerning the answers given to the question "What are your opinions as regards using Edmodo?" in the preliminary evaluation form

\begin{tabular}{|l|l|c|}
\hline Teachers (31 people) & \multicolumn{1}{|c|}{ Perceptions towards using Edmodo } & F \\
\hline \multirow{2}{*}{} & Positive opinions & 16 \\
\cline { 2 - 3 } & Does not have information about the application & 15 \\
\hline
\end{tabular}

An examination of Table 4 shows that among the 31 answers to the question "What are your opinions as regards using Edmodo?" 16 people provided positive opinions whereas 15 people stated that they did not have any information on the application. 
Table 5. Findings concerning the answers given to the question "Briefly define Edmodo content management system" in the preliminary evaluation form

\begin{tabular}{|l|l|c|}
\hline Teachers (31 people) & \multicolumn{1}{|c|}{ Defining Edmodo } & F \\
\hline & Social education network & 18 \\
\cline { 2 - 3 } & Does not have information about the application & 13 \\
\hline
\end{tabular}

An examination of Table 5 shows that among the 31 answers to the question "Briefly define Edmodo content management system" 18 people indicated "social education network" and 13 people said that they did not have any information on the application.

Table 6. Findings concerning the answers given to the question "What are the contributions made by Edmodo to learning process?" in the preliminary evaluation form

\begin{tabular}{|l|l|c|}
\hline Teachers (31 people) & \multicolumn{1}{|c|}{ Contributions made by Edmodo to learning process } & F \\
\hline & Fast communication & 18 \\
\cline { 2 - 3 } & Does not have information about the application & 11 \\
\hline
\end{tabular}

An examination of Table 6 shows that among the 31 answers to the question "What are the contributions made by Edmodo to learning process?" 18 people stated fast communication and 11 people said that they did not have any information on the application. Research participants underlined that Edmodo applications makes learning smarter by adding a value of communication and it makes a need for upgrading knowledge on this new application.

Table 7. Findings concerning the answers given to the question "What are the contributions made by Edmodo to learning process?" in the preliminary evaluation form

\begin{tabular}{|l|l|c|}
\hline Teachers (31 people) & \multicolumn{1}{|c|}{ Contributions made by Edmodo to learning process } & F \\
\hline & It affects education positively & 17 \\
\cline { 2 - 3 } & Does not have information about the application & 14 \\
\hline
\end{tabular}

An examination of Table 7 shows that among the 31 answers to the question "What are the contributions made by Edmodo to learning process?", 11 people stated that it supported individual learning, 6 people said "education opportunity outside school", and people 14 said that they did not have any information on the application.

\subsection{Findings on final evaluation based on the outcomes of training}

Final evaluation questions consist of 6 open ended questions. Themes regarding open-ended final evaluation questions are given below.

Table 8. Findings concerning the answers given to the question "I have detailed information on the nature of Edmodo content management system?" in the final evaluation form

\begin{tabular}{|l|l|c|}
\hline Teachers (21 people) & \multicolumn{1}{|c|}{ Awareness concerning Edmodo } & F \\
\hline & Those who have information about Edmodo & 21 \\
\hline
\end{tabular}


After the series of seminars, as can be seen in Table 8, to the question "I have detailed information on the nature of Edmodo content management system?", 21 people stated that they had information about Edmodo.

Table 9. Findings concerning the answers given to the question "I know the impact of Edmodo content management system on learning-teaching process" in the final evaluation form

\begin{tabular}{|l|l|c|}
\hline Teachers (21 people) & \multicolumn{1}{|c|}{ The impact of Edmodo on learning-teaching process } & F \\
\hline & It affects learning-teaching process positively & 21 \\
\hline
\end{tabular}

As can be seen in table 9, to the question "I know the impact of Edmodo content management system on learning-teaching process", 21 participants answered that they had information on the impact of Edmodo content management system on education process. This shows that research participants increased the awareness on changing learning contexts by the use of technology.

Table 10. Findings concerning the answers given to the question "I know that Edmodo content management system makes contribution to the professional development of teachers who use it" in the final evaluation form

\begin{tabular}{|c|l|c|}
\hline Teachers (21 people) & Contribution of Edmodo to professional development & F \\
\hline & It affects professional development positively & 21 \\
\hline
\end{tabular}

Seminars are tools for the professional development. As can be seen in table 10, to the question "I know that Edmodo content management system makes contribution to the professional development of teachers who use it", 21 people answered that they had information on the impact of Edmodo content management system on the professional education of teachers.

Table 11. Findings concerning the answers given to the question "I have information on the usage of Edmodo content management system?" in the final evaluation form

\begin{tabular}{|l|l|c|}
\hline Teachers (21 people) & \multicolumn{1}{|c|}{ Awareness for Edmodo usage } & F \\
\hline & Those with knowledge on Edmodo usage & 21 \\
\hline
\end{tabular}

As can be seen in table 11, to the question "I have information on the usage of Edmodo content management system?" 21 people answered that they had information on using Edmodo.

Table 12. Findings concerning the answers given to the question "I have information on what can be done as teacher, student and parent in Edmodo content management system?" in the final evaluation form

\begin{tabular}{|l|l|c|}
\hline Teachers (21 people) & \multicolumn{1}{|c|}{ Using Edmodo as teacher, student and parent } & F \\
\hline & Characteristics of Edmodo & 21 \\
\hline
\end{tabular}


As can be seen in table 12, to the question "I have information on what can be done as teacher, student and parent in Edmodo content management system?" 21 people answered that they had information on the characteristics of Edmodo.

Table 13. Themes obtained as regards 6 th question in the final evaluation interview form

\begin{tabular}{|c|c|c|}
\hline Teachers (21 people) & Perceptions on the effectiveness of the seminar & F \\
\hline & Acquired knowledge and skills & 21 \\
\hline
\end{tabular}

As can be seen in table 13, to the question "Please write down the knowledge and skills you acquired on Edmodo Content Management System" in the end of the seminar, 21 people stated that they were knowledgeable about the characteristics of Edmodo.

\section{Conclusion and Recommendations}

The conclusions obtained from the research are explained consistent with sub-objectives and findings.

\subsection{Knowledge level of teachers concerning Edmodo Content Management System}

Within the framework of the research, a preliminary evaluation form was applied in order to assess the knowledge and skill levels of teachers concerning Edmodo content management system prior to the 10 hours seminar applied to the teachers. The prepared preliminary evaluation form was prepared taking the content of the seminar into consideration. After the seminar, a post-test was prepared and applied so as to evaluate the knowledge acquired during the study. Seminars were organized to make a change of according to the obtained findings, it was found out that teachers did not have adequate information on Edmodo content management system before the seminar but that their awareness related to Edmodo increased after the series of seminar which was shown by their answers. [25] obtained the same conclusion in their study.

\subsection{Opinions as regards the contribution of Edmodo content management system on learning-teaching process}

Another sub-objective of the study was the contribution of Edmodo content management system on learning-teaching process. When we examine the foregoing, it has been found out that the teachers who attended the seminar did not have adequate information about Edmodo content management system prior to the seminar. During the seminar which continued for 5 weeks, information was given to the teachers on Edmodo content management system and its usage and several applications were performed. Teachers who attended the seminar entered Edmodo system both as student and teacher and contributions that Edmodo content management system could make to learning-teaching process were discussed. At the end of the seminar process participants stated that they supported the view that Edmodo content management system could be effective on 
learning-teaching process. In their study, [26] concluded that $50 \%$ of students stated that Edmodo increased their learning. [27] argues that Edmodo ensures healthy communication not only in classroom environment but also outside the classroom.

\subsection{Opinions of teachers concerning Edmodo usage at the end of Edmodo content management system seminar}

By means of Edmodo learning environment, teachers can increase the motivation of students for the class, reach students easily, perform group works and support cooperative learning, participate in groups in various parts of the world and follow the developments in their field and other fields which, in turn, contributes to their professional development. In this study the participants were not knowledgeable about Edmodo content management system prior to the seminar, but they provided positive opinions about Edmodo after the seminar. This result is similar to other studies in the literature [27, 28]. As Edmodo has a multi-functional learning and teaching opportunities through infrastructure and learning styles, after series of seminars, research participants recognized the merits of group work, cooperative learning which make their learning motivation to the learning tasks.

\subsection{Recommendations}

Taking the contributions made by technology to education today, encouraging activities can be performed for the teachers to use Edmodo content managerial system, which is free, easy-to-use and safe for information sharing, in their classes in order to make learning environment more efficient. Edmodo content managerial system can be used to increase the responsibility of students towards the class in their learning environment.

As schools are change agents to diffuse create knowledge through the merits of technology, professional development can be gained and school can make adoptions to be smart learning context. When they become smart learning context, there is an intensified need to create technology supported learning and teaching environments. Being a leader of managing learning environments through the use of new technology and application is essential. Therefore, teachers as leaders of classrooms need to upgrade their knowledge in the use of towards digitalization. Within the mission of this way, entrepreneurship and innovation in schools through the managerial and technological attempts are essential $[27,28]$.

School administrators-leaders should consider many factors in order to provide successful education. These factors are curriculums, economic sources, competition and regulations. In modern education systems, school administrators should work with many stakeholders with an interactive way. School governance foresees that all stakeholders should be involved in decision making process in order to increase human rights values [31]. Headmasters and teachers as partners of school culture need to concentrate on the use of Edmodo in order to support learning and teaching. This way of learning become a step to diffuse digitalization to make smart learning context in order to enhance learning [32]. 
Teachers in different parts of the world in the same branch can meet at certain times in Edmodo settings and transfer each other new technologies and methods they use in their classes. For this reason, it is recommended that teachers at secondary stage should be member of Edmodo so that they can obtain contribution to their professional development and knowledge of field.

Both educators, administrators and learners can benefit blockchain powered applications. Educators can efficiently use this kind of application for storing or sharing teaching material or activities. On the other hand, administrators can record degrees of students and open access for other institutes [18]. Blockchain will provide administrators to make their organizations more secure and reliable. Moreover, blockchain will allow learners to access to education easier and more affordable. As the blockchain applications are decentralized, directly communicating with educators is possible [33].

This study was conducted with teachers at secondary stage of Ministry of National Education. Further studies are advised to consider different sample groups.

Teachers can cooperate with parents using Edmodo learning environment and increase the responsibly of students towards class.

Technology, which exists almost in every part of life, has started to make traditional methods become insufficient in every field. Therefore, especially in 2000's studies and searches for new methods have seriously increased. Ministry of National Education is advised to develop educative learning environments according to education needs and infrastructure [29].

\section{$5 \quad$ References}

[1] Chen, R. J. Investigating models for preservice teachers' use of technology to support student-centered learning. Computers \& Education, 2010, 55(1), 32-42. https://doi.org/10. 1016/j.compedu.2009.11.015

[2] Govender, D.; Govender, I. The relationship between information and communications technology (ict) integration and teachers' self-efficacy beliefs about ict. Education as Change, 2009, 13(1), 153-165. https://doi.org/10.1080/16823200902943346

[3] Aksal Altınay, F. Are headmasters digital leaders in school culture? Education and Science, 2015, 40 (182), 77-86. https://doi.org/10.15390/eb.2015.4534

[4] Hew, K.F.; Brush, T. Integrating technology into K-12 teaching and learning: Current knowledge gaps and recommendations for future research. Educational technology research and development, 2007, 55(3), 223-252. https://doi.org/10.1007/s11423-006-9022 $\underline{-5}$

[5] Lawless, K.A.; Pellegrino, J.W. Professional development in integrating technology into teaching and learning: Knowns, unknowns, and ways to pursue better questions and answers. Review of Educational Research, 2007, 77(4), 575-614. https://doi.org/10.3102/ $\underline{0034654307309921}$

[6] Boshuizen, H.P.A.; Wopereis, I.G.J.H. Pedagogy of training in information and communications technology for teachers and beyond. Technology, Pedagogy and Education, 2003, 12(1), 149-159. https://doi.org/10.1080/14759390300200150

[7] Lim, C.P.; Ching, C.S. An activity-theoritical approach to research of ICT integration in Singapore schools: Orienting activities and learner autonomy. Computers \& Education, 2004, 43(3), 215-236. https://doi.org/10.1016/j.compedu.2003.10.005 
[8] Schwartz, H. Facebook: The new classroom commons. The Chronicle of Higher Education, 2009, 56(6), B12-B13.

[9] Sekkal, H., Amrous, N., \& Bennani, S. (2019). Knowledge Management and Reuse in Virtual Learning Communities. International Journal of Emerging Technologies in Learning (iJET), 14(16), 23-39. https://doi.org/10.3991/ijet.v14i16.10588

[10] Ajjan, H.; Hartshorne, R. Investigating faculty decisions to adopt Web 2.0 technologies: Theory and empirical tests. The Internet and Higher Education, 2008, 11(2), 71-80. https:// doi:10.1016/j.iheduc.2008.05.002

[11] Karpinski, A.C.; Duberstein, A. A description of facebook use and academic performance among undergraduate and graduate students. In American Educational Research Association Annual Meeting, San Diego, California, 2009.

[12] Altınay, F.; Altınay, M.; Dagli, G.; Altınay, Z. Being leader in global citizenship at the information technology age. Quality \& Quantity, 2018, 52(1), 31-42. https://doi.org/10.10 07/s11135-017-0585-5

[13] Karasel, N.; Altınay, Z.; Altınay, F.; Dagli, G Paternalist leadership style of the organizational trust. Quality \& Quantity, 2018, 52(1), 11-30. https://doi.org/10.1007/s1113 $\underline{\text { 5-017-0580-x }}$

[14] Warner, B.; Esposito, J. What's not in the syllabus: Faculty transformation, role modeling and role conflict in immersion service-learning courses. International Journal of Teaching and Learning in Higher Education, 2009, 20(3), 510-517.

[15] Junco, R. Too much face and not enough books: The relationship between multiple indices of Facebook use and academic performance. Computers in Human Behavior, 2012 28(1), 187-198. https://doi.org/10.1016/j.chb.2011.08.026

[16] Rakic, S., Tasic, N., Marjanovic, U., Softic, S., Lüftenegger, E., \& Turcin, I. (2020). Student Performance on an E-Learning Platform: Mixed Method Approach. International Journal of Emerging Technologies in Learning (iJET), 15(02), 187-203. https://doi.org/10. 3991/ijet.v15i02.11646

[17] Maguth, B.M.; Harshman, J.R. Social networking and the social studies for citizenship education. Journal of the Research Center for Educational Technology, 2013, 9.

[18] Brady, K.P.; Holcomb, L.B.; Smith, B. V. The use of alternative social networking sites in higher educational settings: A case study of the e-learning benefits of Ning in education. Journal of Interactive Online Learning, 2010, 9(2).

[19] Chen, G.; Xu, B.; Lu, M.; Chen, N.S. Exploring blockchain technology and its potential applications for education. Smart Learning Environments, 2018, 5(1), 1 https://doi.org/10. 1186/s40561-017-0050-X

[20] Sun, H., Wang, X., \& Wang, X. (2018). Application of blockchain technology in online education. International Journal of Emerging Technologies in Learning (iJET), 13(10), 252259. https://doi.org/10.3991/ijet.v13i10.9455

[21] Grech, A; Camilleri, A.F. Blockchain in Education. Publications Office of the European Union, Luxembourg, 2017, 132 S, (JRC Science for Policy Report), urn:nbn:de:0111-pedocs- 150132

[22] Denzin, N.K.; Lincoln, Y. S. Collecting and interpreting qualitative materials; SAGE: London, United Kingdom, 2003.

[23] McMillan, J.H.; Nash, S. Teacher Classroom Assessment and Grading Practices Decision Making. Proceedings of the Annual Meeting of the National Council of Measurement in Education, NewOrleans, United States, 2000.

[24] Merriam, B.S. Nitel Araştırma Desen ve Uygulama İçin Bir Rehber, (tr ed: Turan, S.); Nobel Akademik, Ankara, Turkey, 2013. 
[25] Yıldırım, A. ve Şimşek, H. Sosyal Bilimlerde Nitel Araştirma Yöntemleri, 9th ed.; Seçkin Yayınevi: Ankara, Turkey, 2013

[26] Kongchan, C. How a non-digital-native teacher makes use of Edmodo. 2012. Available online: www.conference.pixel-online.net (accessed on 3.9.2019)

[27] Dere, E.; Yücel, Ü.A.; Yalçınalp, S. İlköğretim öğrencilerinin eğitsel bir çevrimiçi sosyal öğrenme ortami olan edmodo'ya ilişkin görüşleri. Ilkogretim Online, 2016, 15(3). https:// doi.org/10.17051/io.2016.49794

[28] K1lıckaya, F. Edmodo: Make your language classroom o communit. AATSEEL Newsletter, 2012 55(1), 7-10.

[29] Altinay, F.; Fedai, L.; Altinay, Z.; Dagli, G. The Impact of Open Leadership in Being Learning Organisations for Professional Learning. In Proceedings of the 9th International Conference on Computer Supported Education, Porto, Portugal, 2017, 1(FOLSC), 732-735 https://doi.org/10.5220/0006384807320735

[30] Altinay, F.; Dagli, G.; Altinay, Z. Role of technology and management in tolerance and reconciliation education. International Journal of Methodology, 2017, 15(3), 68-72.

[31] Lesinger, F. Y.; Altinay, F.; Altinay, Z.; Dagli, G. Examining the role of leadership, trust for school culture and policy. Quality \& Quantity, 2018, 52(2), 983-1006. https://doi.org/ 10.1007/s11135-017-0553-0

[32] Gurbuzer, E.; Altınay, F.; Altınay, Z; Dagli G. An evaluation of educational and administrative decision making process in tolerance school context for job motivation. Quality \& Quantity,2018, 52(2),1059-1076.https://doi.org/10.1007/s11135-017-0557-9

[33] Özdilekler, M.A.; Altınay, F.; Altınay, Z.; Dagli G. An evaluation of class-teachers' roles in transferring values. Quality \& Quantity, 2018, 52(2), 1043 https://doi.org/10.1007/s1113 5-017-0556-X

[34] Garbade, M.J. The blockchain technology and the tokenization of learning. Altcoin Magazine, 2018

\section{Authors}

Prof. Dr. Fahriye Altinay is Director of Graduate School of Educational Sciences at Near East University. She is co-chair of Societal Research and Development Center. Her research interests are management, disability, smart society, online education

Dr. Ozge Beyatli is graduated from Near East University. She is working at Ministry of Labor and Social Security. Her research interest is computer education. Email:ozge beyatli@hotmail.com

Prof. Dr. Gokmen Dagli is Vice rector of University of Kyrenia. Dean of Faculty of Education and Head of department of educational management in Near East University.Email: gokmen.dagli@kyrenia.edu.tr

Prof. Dr. Zehra Altinay is head of department of educational sciences at faculty of education. She is vice director of graduate school of educational sciences at Near East University. She is co-chair of Societal Research and Development Center. Her research interests are management, disability, online education. Email: zehra.altinaygazi@neu.edu.tr

Article submitted 2020-02-04. Resubmitted 2020-03-27. Final acceptance 2020-03-22. Final version published as submitted by the authors. 